\title{
ブラウン腫瘍に伴う病的骨折の一症例
}

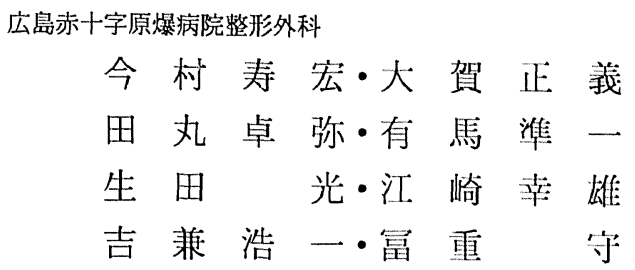

\section{A case of pathological fracture due to Brown tumor}

by

Toshihiro Imamura, Masayoshi Oga, Takuya Tamaru, Junichi Arima, Kou Ikuta, Yukio Esaki, Kouichi Yoshikane and Mamoru Tomishige

Hiroshima Red Cross Hospital And Atomic-Bomb Survivors Hospital

Secondary hyperparathyroidism is a well-known complication of renal failure. A rare manifestation of secondary hyperparathyrodism is the "Brown tumor" of bone. A 44-year-old woman who suffered from a pathological fracture due to Brown tumor is described. We perform osteosynthesis soon after injury allowing the patent to move by herself and significantly improving her quality of life. We consider that it is necessary to prepare bone cement, bank bone to support the weakness of bone structure.

Key words : brown tumor (ブラウン腫瘍), secondary hyperparathyroidism (二次性副印状腺㙨能元 進症), pathological fracture (病的骨折)

は じめに

慢性腎不全に対する血液透析療法の発達・普及によ り長期透析患者が増加し，Ca 代謝障害に起因する二 次性副甲状腺機能え進症がその合併症として問題となっ た. 今回, 我々は透析歴の無い二次性副甲状腺機能立 進症に合併したブラウン腫瘍により病的骨折をおこし た症例を経験したので文献的考察を加え報告する．

症例

症例 : 44歳, 女性.

主訴 : 左股関節痛

現病歷 : 自転車にて走行中, 停止しょうと左足を着 いた際，左股関節痛をきたし起立不能となった。

既往歷 : 糖尿病, 急性腎孟腎炎による, 慢性腎不全,
二次性副甲状腺機能穴進症

\section{初診 時 所見}

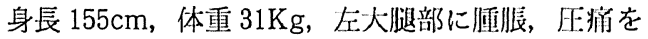
認めた。単純 X 線にて，左大煺骨怰子下に冎折を恋 め, 転子下から遠位に加诽溥化した骨皮斦を伴っ た榧胞状陰影を認め, 病的骨折と考えられた（図 1).

初診時臨床検查では著明な貧血, 高リンIIII症, 高

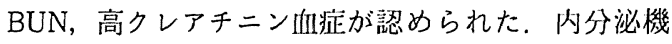
能検査では Ca 摄取量やPTH のパルス的な变動に影 響されないHS-PTH が高值であった。 また生物学的 活性をむたないC 端側フラグメントである C-PTH が高値であり，慢性腎不全に伴う一次性副甲状腺機能 亢進症に，特徴的な所見であった（表 1).

全身の X 線像では副甲状腺機能九進症に合致する 


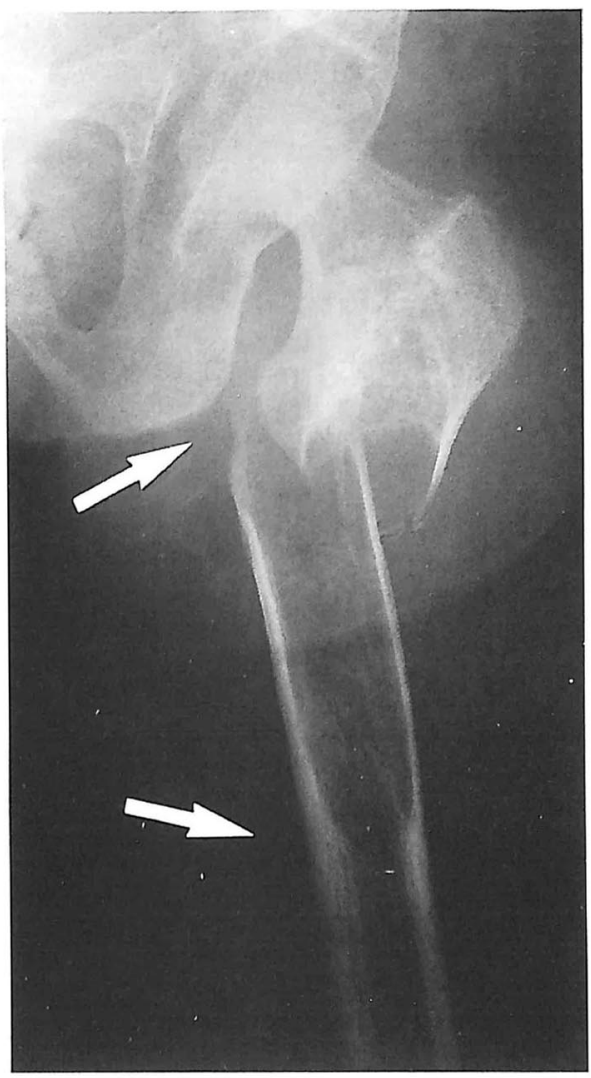

图 1 入院時単純レ線 左大煺骨近位部に落泡状陰影認める。

表 1 初衡時臨㕅検榃

末梢I血液 般梌应

WBC $10400 \uparrow$ RBC 275万 $\downarrow \quad \mathrm{Hb} 7.7 \mathrm{~g} / \mathrm{d} 1 \downarrow$

IIII被生化学的梌售

Na $133 \mathrm{mEq} / 1 \quad \mathrm{~K} 4.0 \mathrm{mEq} / 1 \quad$ Ca $3.9 \mathrm{mEq} / 1$

P $\quad 5.5 \mathrm{mEq} / 1 \uparrow$ BUN $110 \mathrm{mg} / \mathrm{d} 1 \uparrow \operatorname{Cr} 5.5 \mathrm{mEq} / 1 \uparrow$

内分泌機能検在

HS-PTH $14000 \mathrm{pg} / \mathrm{ml} \uparrow \quad \mathrm{C}-\mathrm{PTH} \quad 25.6 \mathrm{ng} / \mathrm{ml} \uparrow$

骨病变を呈していた。手指基節骨を中心とした骨膜下 骨吸収像，頭惪骨の salt-and-pepper appearance， 脊惟での rugger jersey appearance，また右大腿骨 にむ限局性に韭薄化した骨皮質を伴った器饱状陰影， つまりブラウン腫癔を認めた（図 2 ).

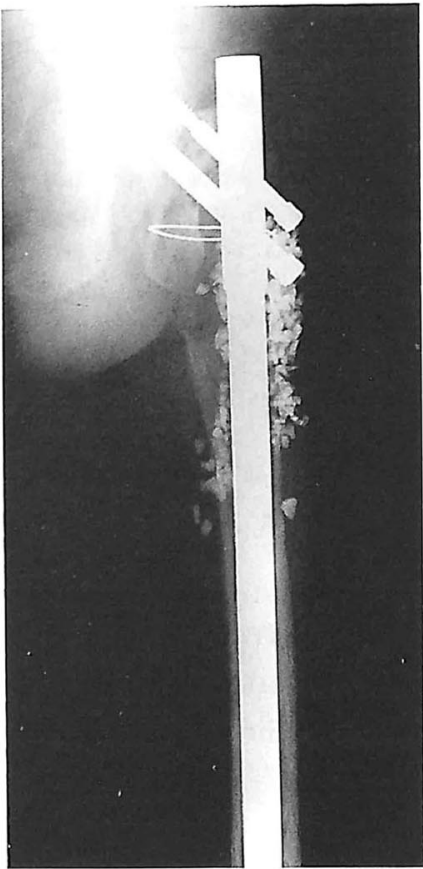

図 3 術後単純レ線 Russel-Taylor の噵内釘にて骨接合.

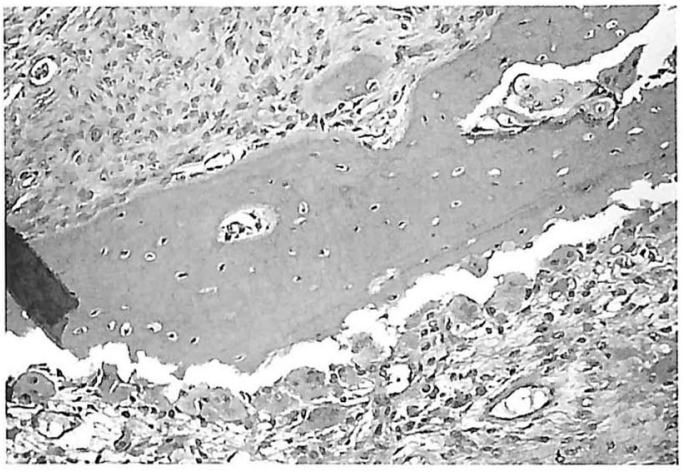

图 4 顕微鏡写真 (H-E 染色)

骨皮質には広筫囲に osteoclast の集簇を認めた。

$$
\text { 手術 }
$$

手術は Russel-Taylor の䯣内釷を用い骨接合術を 施行，垩胞状陰影を呈する病巣部より赤褐色の軟らか い腫瘍を認めた。腫瘍を掻破した部位にハイドロキシ アパタイトを充填した（図 3 ). 病理所見にて腫痬組 織は骨䯣，肉芽組織及び fibrin より構成されていた。 また韭薄化した骨皮質には広範囲に osteoclast の集 簇を認めた（図 4 ) . 


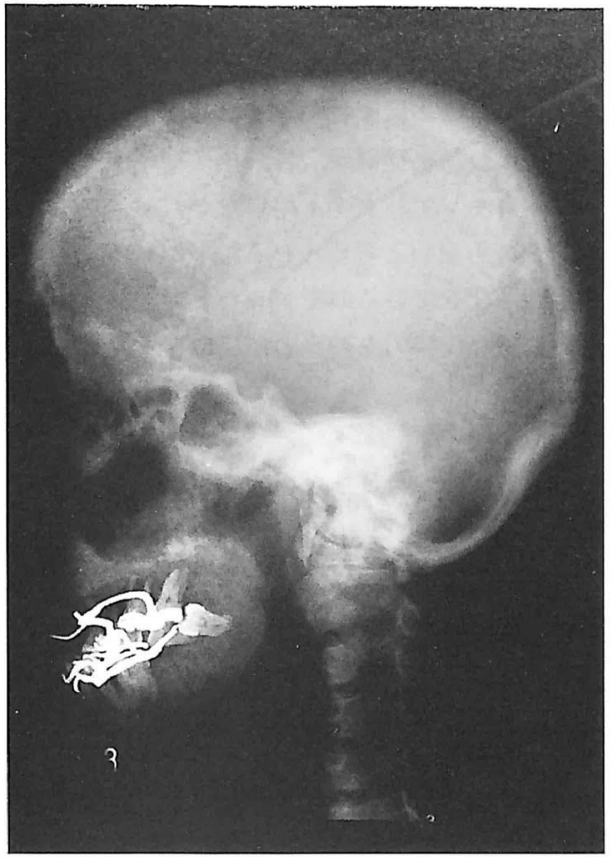

a

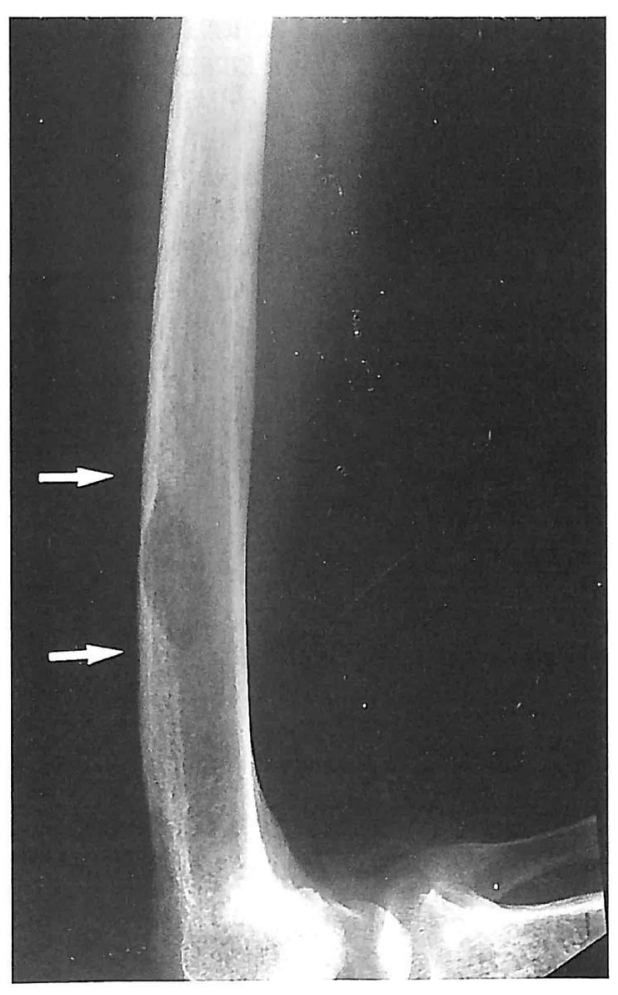

c

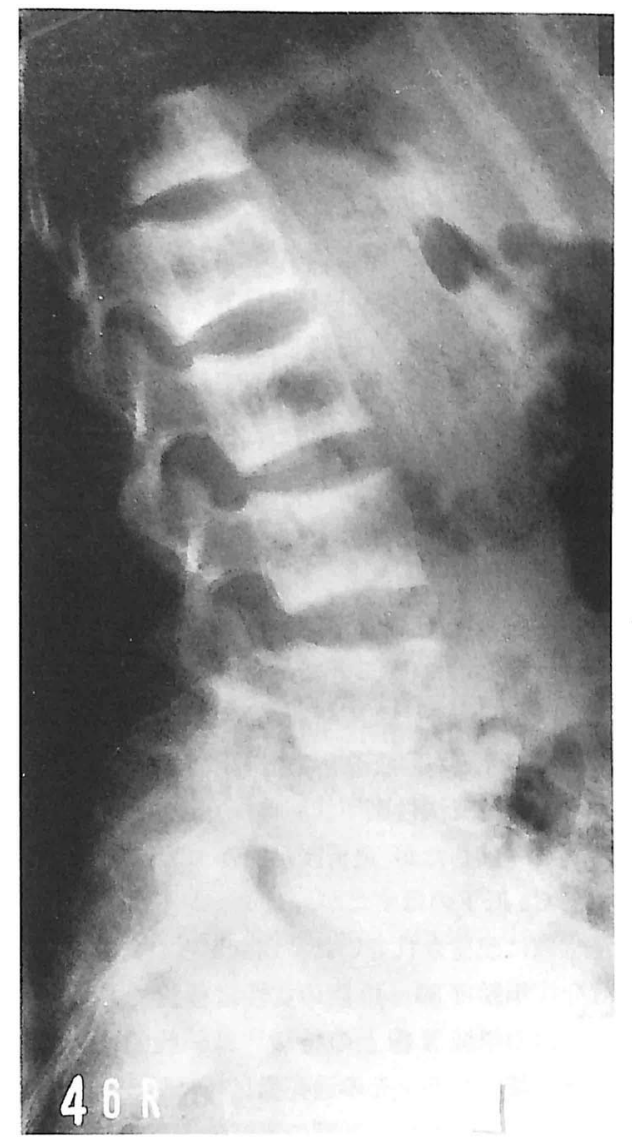

b

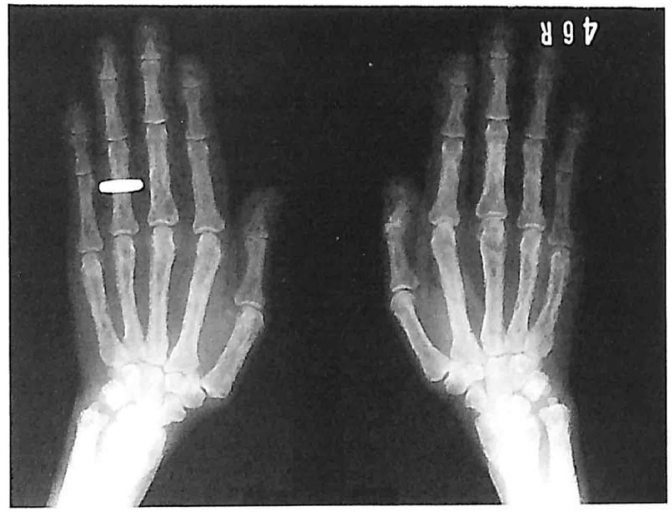

d

図 2 全身単純レ線

a salt-and-pepper appearance

b rugger jersey spine

c brown tumor

d subperiosteal resorption 


\section{術 後 経 過}

術後 6 日より下肢筋力訓練開始，18日よりベッド 上端座位，24 日より車椅子による移動を許可。また 術後, 一過性に觜機能低下を認めた為, 初めて血液透 析を間歇的に実施した。患者は車椅子にて移動できる ことを喜んでいた，術後 60 日に慢性㫮不全，及び桾 尿病管理の為に腎臟内科へ転科した。転科直後は全身 状態良好であったが術後 70 日より持病の肛門周囲捗 瘍增悪. 術後 90 日に壊死性筋膜炎による敗血症の為, 死亡した。

\section{考察}

二次性副甲状腺機能穴進症に伴うブラウン腫崵が最 初に報告"されたのは1963 年である.

S. Ozen らによると 1994 年までの約 30 年間報告 は極めて少なく殆どが血液透析に合作した症例 ${ }^{2)}$ であっ た．今回，我々は二次性副甲状腺機能宇進症に伴うブ

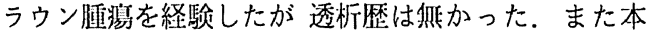
来なら血清 $\mathrm{Ca}$ 低下のはずだが，ビタミン $\mathrm{D}$ 留剤投与 により正常值に改善されていた. Black らの文献 ${ }^{3)} に$

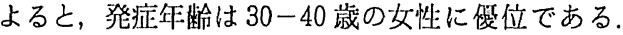

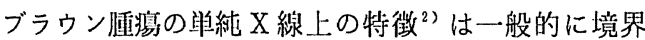
不明腹な透亮像である。その透亮像は時に骨皮質にま で及び，新しく形成された骨膜の薄い外皮により㠅わ れている，病理学的には骨随は豐富な血管をもつ "loose connective tissue" に置掺されており，残存 した cancellous bone trabeculae では破骨細枹の活

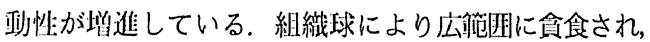

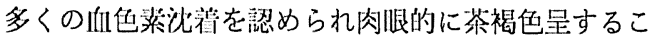

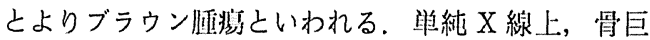

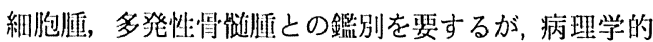

所見にて鑑別しうる.

また手術に際し，腫瘍範囲が広く，広大な骨欠損部 を補強するのに自家骨のみでは，不十分であるので骨 折部位より腫瘍掻破後，骨欠損を補強する為に我々は ハイドロキシアパタイト用いたが骨セメントや銀行骨 用いるのも良いと考えられる．骨折部位は骨皮質がか なり菲薄化しているのでプレートで骨接合するよりは 䯣内釷用い支持力を補うのが良いと考えられた。

\section{結語}

1.今回我々はブラウン腫瘍による病的骨折の一症 例を経験した。

2，骨接合術を受傷後，早期に行うことにより車椅 子移動が可能となり患者の quality of life は改善さ れた。

3，手術に際して，骨皮質の脆弱さ及び欠損部を補 う為にも骨セメント，銀行骨，等の骨補填材料を準備 しておく必要があると考えられた。

\section{参 考 文 献}

1) Adam Greenspan : ORTHOPEDIC RADIOLOGY A PRACTICAL APPROACH LIPPINCOTT pp. 15.9-15.23 \& 21.2-21.6

2) Fordham, C. C., Williams, T. F : Brown tumor and secondary hyperparathyroidism. N. Engl. J. Med., 269, 129, 1963.

3) Schajowicz F : Brown tumor. Tumors and tumorlike Lesions of Bone and Joints, Springer Verlag, pp. 500-506, 1981.

4) S. Ozen, et al. : Brown tumor as a complication of secondary hyperparathyroidism in Uraemia : A Case Report International Urology and Nephrology 26(5) pp. 481-484, 1994. 